\title{
A visão do trono Exegese e hermenêutica de Ap.4
}

Isidoro Mazzarolo

\section{Introdução}

O mundo de hoje carece de visionários, de pessoas intuitivas e de sensibilidade. A física, a astronomia, a engenharia genética e a manipulação da vida obstruem a sensibilidade cósmica, a visão total do ser no universo. Existem muitos futurólogos, astrólogos, leitores de cartas e búzios, mas não há mais visionários que sejam luminares, indicadores da realidade coletiva e ampla. Os presidentes das grandes potências são cegos, loucos, vazios de ser. Acreditam que a arma mais potente lhe dá o direito de dominar, matar e devorar vidas como feras sanguinárias. Os tiranos sempre foram sanguinários, cretinos e dragões dos pobres e pequenos e ainda ostentam o direito de benfeitores (Lc 22,24-25).

O trabalho que apresentamos não tem muitas pretensões futurísticas, sonha no engajamento da práxis com a expressão teórica e quer provocar a sensibilidade do leitor para a contribuição no surgimento de uma "forma mentis", capaz de acreditar na superação, na utopia e na transformação da realidade presente. Nada é tão caótico que não possa ser paradisíaco. Nada é tão perverso que não possa ser transformado em promissor. Nesta ótica queremos fazer de nosso artigo uma contribuição para reforçar a importância e a compreensão desta realidade que são as visões no livro do Apocalipse e atualizar esta mensagem tão bela, pois, partindo de uma situação de perseguição e desespero, ele conduz os seus leitores a uma união de resistência e esperança. 
Os tempos do Apocalipse (entre 90 e 120 d.C.) são de sofrimento, perseguição e medo. Os "dragões" dos anos de João eram o Império romano e a Sinagoga, que ele denomina de Babilônia. Na época, o dragão que combatia a mulher (Ap 12) falava latim, hoje ele fala inglês e uma língua semítica. O escritor/autor (João) está exilado na ilha de Patmos e a maioria dos cristãos é perseguida por que era vista como movimento de rebeldes, subversivos e perigosos ao sistema romano e sinagogal. O livro é um conjunto sincrônico de visões com estrutura setenária (grupos de sete), sempre ligado seqüencialmente, o último passo de um conjunto se liga ao primeiro conjunto imediatamente posto. Contudo, esses conjuntos sincronizados e seqüenciais podem ser considerados uma única visão se tomarmos os três primeiros capítulos como uma introdução, uma visão preliminar, mas a motivação e o centro fixado, em torno do Cordeiro e da visão do céu, começa quando o autor usa o verbo "oraô" = ver $(4,1)$ e usa este mesmo verbo no início de cada parte até o c. 21,1 quando ele conclui a última visão do novo céu e da nova terra.

As visões são sempre algo que transcende a compreensão imediata, escapa ao dado empírico da razão. A visão situa-se no horizonte da percepção extra-sensorial, mesmo que a forma de sua captação tenha o sentido de ser materializada, concreta e verificável.

\section{Alguns conceitos de visão ${ }^{1}$ :}

A visão seria o ato de ver, resultado da ação do olhar (Spasa Calpe, v.LXIX), intimamente ligada à aparição, ao contato e comunicação com imagens, sons e linguagem. Ela traduz o encontro "real" do vidente com o que vê, e esteve sempre presente em todas as culturas antigas e nos povos de todos os tempos. Por mais que o racionalismo e o ceticismo tentem combater, o instinto e a intuição da visão acabam prevalecendo. Conforme Becatti ${ }^{2}$, a visão permite recriar, no ânimo do vidente, imagens longínquas com tal intensidade que parecem ser vistas com os olhos como se fossem reais e estivessem presentes. Becatti parte do conceito grego "phantasia", mas a visão não está alicerçada na fantasia, no imaginário, ela se alicerça na percepção que vem de fora. $\mathrm{O}$

\footnotetext{
${ }^{1}$ Visão = "É o ato ou efeito do ver, imagem vã, que se acredita ver em sonhos, loucura, fantasia, quimera ou revelação" (DICIONÁRIO DA LÍNGUA PORTUGUESA, AURÉLIO. A visão, como "horama", do grego, é "algo visto, percepção em estado de vigília, algo visto em estado de êxtase ou quase hypnose, algo relativo à percepção", DIMITRIKOS, NEON ORTOGRAPHIKON HERMENEYTIKON LEXIKON, Athenas, 1970. Pode ser uma percepção do mundo exterior, do mundo sobrenatural com implicações no mundo concreto, terreno e na realidade sociológica. A alucinação é a visão falsa da sobrenaturalidade ou da realidade. A cegueira é a antítese da visão (é o não ver, não entender, não interpretar).

2 BECATTI, G., Enciclopedia dell'arte antica, "visione", 1966.
} 
conceito grego de "orâ̂" = ver, difere do conceito de "phantasia" que não raro resulta do imaginário interno, do sonho ou da utopia.

No sentido próprio, a visão é o ato de ver, do alcance da vista que permite atingir o ente corpóreo. Em geral, é o ato de ver no sentido de tomar consciência, conhecer, compreender ou mesmo de ocupar-se com algo ${ }^{3}$. No aspecto bíblico, as visões são as comunicações de Deus através das quais os videntes tomam conhecimento dos segredos de Deus (Am 3,7), escutam os seus conselhos (Jr 23,18.22), Deus lhes fala em sonhos (Nm 12,6-8) e eles traduzem por palavras o que seu intelecto captou ${ }^{4}$.

No âmbito literário, a visão pode ser compreendida como um fenômeno extraordinário de caráter religioso, o qual consiste em perceber manifestações sobrenaturais. Sob esta ótica, a visão se caracteriza em três aspectos: 1) Corporal - esta acontece sempre no estado de vigília, de contemplação ou aparição;

2) Imaginativa - esta se dá através da manifestação em sonhos nos quais temos dois aspectos possíveis: o primeiro seria uma associação com dados naturalmente possuídos e o segundo originado por uma força totalmente sobrenatural;

3) Intelectual - esta traduz a compreensão da "verdade nua".

\section{A etimologia das visões}

O substantivo "horama" = visão indica, algo que a gente realmente vê, em oposição a uma fantasia ${ }^{5}$. Esta é a visão que, no contexto bíblico, faz o seu ator ver como real, como verídica e não como ilusão. No relato bíblico do Ex 3,3, Moisés não tem uma ilusão da sarça, mas algo real. Complementando o relato, quando o autor(s) do Deuteronômio narra(m) a própria experiência da participação de Deus no Êxodo afirma que não foi apenas um sonho, mas tudo foi real (Dt 4,34). Quer no Testamento de Henoc 99,8 como no Testamento de Levi 8,1 encontramos a combinação do verbo com o substantivo "eîdon horama" (At 12,9) = vi uma visão. A visão é dada, é presenteada como em Gn 15,1 quando Abraão recebe de Deus uma mensagem através da visão ('al t'îrah = sobre a visão, do verbo ver $r a$ 'ah).

Um sinônimo de "horama" é "horasis" = semblante, aspecto: "... nele havia alguém sentado com o semblante de pedra de jáspide" (Ap 4,3). Na

\footnotetext{
${ }^{3}$ Cf. MONLOUBOU, L. "Visão", in: Dicionário bíblico universal. Petrópolis: Vozes, 1997.

${ }^{4}$ HAAG, H. Bibel-Lexicon. Zürich: Verlag, 1968.

${ }^{5}$ BAUER, W., Op. Cit. "horama”, in: BAUER, W., Wörterbuch zum Nenem Testament, Berlin, De Gruyter, 1971.
} 
cultura grega, os substantivos "semblante", "face" sempre foram considerados a expressão do ser. Ver o semblante de alguém era ter uma visão deste ser.

Os verbos gregos principais usados para traduzir a visão são: horâ (45 vezes no Ap) = ver, Ap 4,3; 9,17; theôreô = ver no sentido de perceber, Ap 11,11 (usado aqui como particípio presente, no Ac.) e o verbo blepô = ver, com o sentido de enxergar, identificar e entender. O sentido transitivo do verbo horaô significa ver, observar, reconhecer ${ }^{6}$. No primeiro sentido o verbo horaô $=$ ver, pode ter como sinônimo imediato o verbo "blepô" $=$ ver, olhar. O verbo "horaô" traduz o ato da visão, no seu sentido real, como encontramos na primeira carta de João 1,1: "Aquilo que era desde o princípio, o que ouvimos, o que vimos com nossos olhos..." Na Transfiguração Pedro, Tiago e João vêem Jesus conversando com Moisés e Elias (Lc 9,28-35 e par.). O ato de ver "horaô" traduz a idéia, muito presente no Antigo Testamento, do verbo hebraico "ra'ah", interpretando a imagem de uma visão magnífica, da majestade divina, da glória de Deus e de sua face (Cf. Gn 43,3.5; 46,30; Ap 22,4).

O verbo "theôreô", usado apenas uma vez no Apocalipse $(11,11)$, não traduz o sentido explícito da visão. Usado no particípio, o verbo "theôreô" traduz o sentido do ver com um conceito mais abrangente como expectar, olhar panoramicamente, observar, sem a compreensão profunda do ver?

O verbo mais usado no aspecto das visões é "blépô" = ver, olhar, observar, entender o que o movimento dos olhos percebem ${ }^{8}$. Em toda a Bíblia (LXX), o verbo "blepô" é usado como o ver de modo geral, algumas vezes como um sinônimo de "theôreô" (Ex 4,11; Mt 13,14; Lc 7,21; Ap 3,18).

Para traduzir melhor a idéia de ver-entender, o autor do Apocalipse tem uma preferência específica pelo uso de "horaô", na forma do aoristo (passado narrativo) "eidon" (eu vi, eu entendi, eu reconheci...), cuja forma é igual na primeira pessoa do singular e na terceira do plural. Obviamente, como o narrador das visões se intitula João (Ap 1,1), que recebe de Deus a Revelação $(A p 1,1)$, quase todas às vezes (45 vezes no $A p)$ em que esta forma aparece, refere-se ao narrador, portanto, na primeira pessoa do singular.

\section{O contexto do Apocalipse}

Para entender o Apocalipse faz-se necessário identificar o que acontece no final do primeiro século da era cristã. Acompanhando os escritos do Novo Testamento, observa-se que, a partir da destruição de Jerusalém no ano

\footnotetext{
${ }^{6}$ BAUER, W., Op. Cit. "horaô".

${ }^{7}$ BAUER, W., Op. Cit. "theôreô".

${ }^{8}$ BAUER, W., Op. Cit. "blepô".
} 
de 70 d.C., pelos romanos, em virtude da revolta dos Zelotas e Sicários que iniciou na Galiléia três anos antes, a relação dos judeus com os cristãos começou a ficar cada dia mais complicada. Até o ano de 70, os cristãos costumavam ir para o Templo nos dias de sábado, pois pretendiam discutir com os judeus o cumprimento das profecias a respeito do Messias e sustentar que Jesus era a plenificação das Escrituras (Is 7,14; 11,1-6).

Com a destruição do Templo, os judeus culparam os cristãos, afirmando que eles eram os responsáveis pela vinda da tropa romana, comandada por Vespasiano, e assim caía o símbolo da pátria. A partir desta data, os judeus começam a se reunir em sinagogas e dificultam a presença dos cristãos. O clima de tensão vai até o ano 85 , quando os judeus formalizam a expulsão da sinagoga dos seguidores da nova religião, chamando-os "hereges" e também pronunciam uma maldição formal sobre eles: "Maldito todo o que segue o Nazareno". Da parte do império romano, a perseguição já havia sido iniciada pelo imperador Cláudio (41-54 d.C.), mas acentua-se de modo mais radicalizado com seu sucessor Nero (54-66 d.C.). ${ }^{9}$ Depois do ano de 85 d.C. os cristãos precisam encontrar subterfúgios, esconderijos e estratégias de sobrevivências. Sempre que alguém era identificado como seguidor da "nova religião" era perseguido economicamente, politicamente e, não raro, preso e morto.

As visões do Apocalipse traduzem a Revelação em forma de enigma, de códigos e de linguagem cifrada por razões de sobrevivência e não a necessidade da não identificação por parte do Império. Para evitar que as comunidades fossem privadas de seus líderes, para salvar as famílias de sua mutilação, geralmente os pais, era preciso encontrar caminhos de comunicar mensagens sem que as autoridades reconhecessem o conteúdo. Os códigos fazem surgir os símbolos e a linguagem própria, dificultando a revelação da identidade cristã.

$\mathrm{Na}$ linguagem codificada, Jesus Cristo passa a ser representado pelo Cordeiro, que se torna a chave de leitura do livro. O Cordeiro, uma imagem comum na Palestina e no Oriente Antigo, é o único capaz e digno de abrir os segredos do livro (Ap 5,9). O autor está obrigado ao uso de uma linguagem simbólica usando imagens, figuras e nomes do passado para falar do presente: A besta $=0$ Império; sete cabeças $=$ sete colinas; dez chifres $=$ dez imperadores (Ap 17,9-11). Na história do AT, a Babilônia representava a grande corrompida, agora transferida para o Roma.

\footnotetext{
${ }^{9}$ Sobre a época, a situação ampla que se desenvolve nos conflitos do Apocalipse entre o Império Romano e os cristãos, remetemos ao estudo feito na introdução ao Ap, Mazzarolo, I. Apocalipse, esoterismo, profecia ou resistência? (esp. pp. 14-22).
} 
"O processo regular que os três personagens hostis seguem, por vontade do autor, é curioso e significativo: uma etapa de poder, uma derrota ou revés, se refazem por um momento, até a derrota definitiva. Isso vale para o dragão, a primeira fera e o novo personagem desses dois capítulos dedicados ao julgamento, condenação, execução e lamentação da Grande Prostituta. É a Babilônia histórica que arrasou Jerusalém, é a Roma do culto imperial e feroz perseguidora dos cristãos. É emblema de qualquer cidade ou poder, de qualquer época, que se opõe ao plano divino de salvação por Jesus Cristo. O nome de Babilônia atrai textos de Jr 50-51; o canto fúnebre inspira-se mais em Ez 26-27. Quando o autor procura descrever em código a figura de Roma, quando salta da fera aos chifres, sucede-lhe o que aconteceu a Daniel que se perdeu em alegorias intelectuais pouco convincentes" (Bíblia do Peregrino, $1^{\mathrm{a}}$. ed. Comentário introdutório a Ap 17-18).

\section{As visões no Apocalipse}

O livro do Apocalipse pode ser visto de dois modos: a. Como um conjunto de visões sucessivas e progressivas, desde 1,10, quando o autor recebe a ordem de escrever tudo quanto vê no dia do Senhor, quando começam as visões em cadeia; b. Ele pode ser interpretado como uma visão única 1,1022,15 . Se consideramos, como a maioria dos autores faz, os cc. 1-3, como uma introdução, então, a expressão "depois disso tive uma visão" $(4,1)$, essa seria a grande visão celeste, tendo cenários, personagens e posturas sucessivas, todas integradas umas com as outras.

Todo o livro do Apocalipse está centralizado na visão, no sentido e na apresentação de Jesus Cristo como Cordeiro que liberta e resgata (Mc 10,45), como uma pedagogia da resistência, como uma catequese cristocêntrica da Revelação de Deus para as pequenas comunidades que surgiam e estavam sendo oprimidas pela sinagoga e pelo Império romano ${ }^{10}$. As visões são revelações que inspiram coragem, confiança e motivações para continuar acreditando nas propostas de Jesus Cristo deixadas aos seus discípulos. Nesta visão inaugural (Ap 4,1), o autor centraliza a temática principal do livro (Läpple, 1966, p. 106). Por outro lado, a temática do Cordeiro é também uma retoma-

\footnotetext{
${ }^{10}$ MAZZAROLO, I. Apocalipse, esoterismo, profecia ou resistência? Rio de Janeiro: Mazzarolo editor, 2000, 24.
} 
da das visões messiânicas e profecias do AT, de modo particular do profeta Isaías $(7,14 ; 9,1-6 ; 11,1-9)$. Outros elementos destas visões podem ser vinculados aos temas vocacionais veterotestamentários, os quais desempenhavam um grande papel de encorajamento e resistência diante das dificuldades iminentes da missão. Para Dattler, ${ }^{11}$ parte do material das visões seria tirado de Isaías e Ezequiel, com o objetivo de associar a vocação profética à vocação cristã.

O termo apocalipse vem do grego que significa o contrário daquilo que é usado na linguagem popular. Quando uma situação é caótica, absolutamente crítica ou inexplicável, as pessoas falam que é uma coisa apocalíptica. O Apocalipse é o contrário: é a explicação do fenômeno, é a revelação do segredo e o entendimento do difícil. Revelar é tirar o véu que encobre, que esconde ou que não permite a visualização do objeto.

O autor do livro revela um entendimento perfeito da situação e ele escreve assim como the é mostrado nas visões: "Num domingo (en tê kyriakê hêmera) ouvi uma voz forte atrás de mim, como uma trombeta, dizendo - Escreve num livro o que vês e envia às sete Igrejas..." (Ap 1,10-11).

$\mathrm{O}$ gênero literário apocalíptico envolve o cósmico, o fenomenológico, o enigmático, o final e o patético ${ }^{12}$. As visões percorrem toda a literatura apocalíptica de todas as culturas e povos. A finalidade principal do gênero apocalíptico é esclarecer o enigmático. Para ter alcance a essa esfera "superior" de conhecimentos e compreensões, os videntes sempre fazem uso da imagem, da visão e da revelação. Na verdade, os autores dos apocalipses são sempre videntes que se colocam como servidores, como intérpretes (Ap 1,1) e não como proprietários ou detentores de conhecimentos superiores. Aquilo que lhes é dado a conhecer é algo gratuito, sem méritos e sem privilégios. A visão é graça de graça para permitir fazer conhecer a perfeição e a vontade divina. A visão, no caráter místico, pode transformar o vidente em "entendedor" da visão, visto que ele passa de um expectador fortuito para alguém que entende, decodifica e transmite o que $\mathbf{v e}^{13}$. No caso do Apocalipse de João, ele recebe do anjo a revelação a respeito de Jesus Cristo (Ap 1,1) e deve testemunhar para a comunidade e para todas as Igrejas o que viu (Ap 1,2.9ss). Ele vai "ver" e escrever era, que é e que será a todas as igrejas da Ásia $(\mathrm{Ap} 1,4)$.

$\mathrm{O}$ conteúdo da Revelação é aquilo que vai acontecer em breve ou mais distante, mas vincula os dois tempos: o presente e o futuro. $\mathrm{O}$ autor é um

\footnotetext{
${ }^{11}$ DATTER, F. O livro da Revelação - Comentário sobre o Apocalipse. São Paulo: Loyola, $1977,42$.

${ }^{12}$ MAZZAROLO, I. Apocalipse, esoterismo, profecia ou resistência? 11.

${ }^{13}$ ROSA, E. "Visione", in: Enciclopédia Italiana di Scienze, Lettere ed Arti. Roma: Istituto della Enciclopédia, 1950, 454.
} 
exilado na ilha de Patmos, próximo à cidade de Mileto, e na qualidade de sofredor e experiente da situação, comunica o que sabe sobre o presente e o futuro a seus irmãos no sofrimento (Ap 1,9). "A expressão deve acontecer não significa que as coisas anunciadas vão acontecer independentemente de nós, sem a nossa participação. Isso geraria um sentimento de fatalismo nas pessoas. A expressão deve acontecer não é dita em relação às comunidades que querem colaborar e participar no projeto de Deus, mas é dita em relação ao império romano que pensava poder contrariar ou impedir os planos de Deus"14. "Depois disso vi uma porta aberta no céu e ouvi uma voz de trombeta que me falara no princípio: Sobe aqui e te mostrarei o que vai acontecer depois" (Ap 4,1). Para narrar o que iria ver, o autor faz uso de uma linguagem própria para fortalecer a fé e a coragem dos cristãos em tempos de perseguição pela sinagoga e o império romano.

\subsection{A visão do trono celeste (Ap 4,1-11)}

"Depois disso vi uma porta aberta no céu e ouvi a voz anterior, como a de uma trombeta dizendo-me: Sobe aqui e te mostrarei o que vai acontecer depois. Imediatamente apoderou-se de mim o espirito. Vi um trono colocado no céu e nele sentado alguém cujo aspecto era de jaspe e cornalina; rodeando o trono brilhava um arcor-íris como de esmeralda. Ao redor do trono havia vinte e quatro tronos, e sentados neles vinte e quatro anciãos, com vestes brancas e coroas de ouro na cabeça. Do trono saíam relâmpagos e ouviam-se trovões. Sete tochas de fogo ardiam diante do trono, os sete espiritos de Deus. Diante do trono havia como um mar transparente, semelhante a cristal. No centro, rodeando o trono, estavam quatro seres vivos cobertos de olhos pela frente e por trás. O primeiro ser vivo tinha aspecto de leão, o segundo de touro, o terceiro tinha rosto humano, o quarto tinha aspecto de água voando. Cada um dos seres vivos tinha seis asas, cobertas de olhos por dentro e em volta. Nem de dia nem de noite descansam, dizendo:

Santo, santo, santo,

Senhor Deus Todo-poderoso,

Aquele que era, é e será.

Cada vez que os seres vivos davam glória, honra e ação de graças àquele que vive pelos séculos dos séculos. Os vinte e quatro anciãos se prostram diante daquele que está sentado no trono para adorarem a-

\footnotetext{
${ }^{14}$ MESTERS, C., OROFINO, F. Apocalipse de João; Esperança, Coragem e Alegria. São Leopoldo/Cebi - São Paulo/Paulus, 2002, 17.
} 
quele que vive pelos séculos dos séculos, depondo suas coroas diante do trono e proclamando:

Digno és tu, Senhor e Deus nosso, de receber a glória, a honra e o poder, pois tu criaste todas as coisas; por tua vontade elas não existiam e foram criadas" (Ap 4,1-11).

O autor começa o texto dizendo: "meta tauta eîdon..." = "Depois disso vi..." (Ap 4,1) vinculando o que vinha ou o que havia visto anteriormente com o que estava vendo agora ${ }^{15}$. A visão anterior era do Cordeiro $(1,10 \mathrm{ss})$ que o enviava a escrever as cartas às igrejas indicadas, a fim de que elas conhecessem os mistérios profundos da revelação e salvação. Agora, o autor afirma: "Eu vi", asseverando que não se trata de sonho, ilusão ou fantasia. Ele viu o céu e nele uma porta aberta. O cenário é apresentado como real, verídico e o autor não está sob efeitos de condicionamentos psicológicos ou de ilusionismos. Essa certeza e autenticidade podem pertencer ao gênero do êxtase. $^{16}$

Aqui João vai entrar num cenário celeste, a porta está aberta, a passagem é permitida, ele é convidado a subir para ver o que o Espírito vai lhe mostrar e é necessário que aconteça (Ap 4,1). O Cordeiro (Jesus Cristo) que ele tinha encontrado (Ap 1,4-5) é o centro da visão inteira do livro do Ap, mas aqui, ele estará diante do trono de Deus. Antes, quando chegara diante do trono $(1,4)$, recebera do Cordeiro a ordem de escrever as cartas para as Sete Igrejas da Ásia (para todas as Igrejas, pois o número sete é uma totalidade). Neste momento, ele avança mais um passo na entrada da tenda celeste e ele vai ver como tudo deverá acontecer. "Nesta visão (Ap 4,1) o autor descreve o tempo e o espaço com a precisão e a beleza do fato real" 17 . sa visão. ${ }^{18}$

Não há como verificar ou certificar-se de onde e quando João teve es-

Entrando no "andar de cima" (o nosso vidente é convidado a subir, e o verbo está no imperativo - "anába" = sobe), lhe é mostrada a realidade mais

\footnotetext{
${ }^{15}$ Poderíamos considerar diferentes secções no livro, a partir da expressão "metá tauta..." (cf. $4,1 ; 7,1.9 ; 15,15 ; 18,1 ; 19,1)$. Mas, a meu ver, é melhor considerar partes da grande visão celeste $(4,1-22,15)$.

${ }^{16}$ LADD, G. Apocalipse, Introdução e comentário, São Paulo, Vida Nova, 2006, 54.

${ }^{17}$ ROLOF, J. Die offenbarung des Johannes. Zürich: Verlag, 1984, 68.

${ }^{18}$ MOUNCE, Robert H., The Book of Revelation, revised, Michigan, Eerdmans Publishing Company, 2008, 117.
} 
íntima e mais completa do trono, da composição dos lugares ao redor trono e quem é verdadeiramente Aquele que nele está sentado. O Cordeiro está no centro da revelação e do anúncio $(1,1)$, é aquele que vai abrir o livro selado (5-6), aquele que resgatou os 144 mil (14,1-13) e aquele que celebra as núpcias da vitória $(19,9)$. O Cordeiro, de pé e vitorioso sobre o mal, é o começo e o fim, a razão primeira e a última de toda a história. Assim, o leitor do livro do Apocalipse poderia ter a certeza de que aquilo que estava lendo seria a absoluta verdade. Aquele que estava no centro, no trono, era o Senhor. E junto dele, no centro da sala real, está o Pai, aquele que confiou sua missão ao Filho e agora o empossa para o julgamento.

\subsection{A descrição do trono}

O autor usa o estilo da visão clássica: "Depois disso, vi uma porta aberta no céu..." (Ap 4,1). Este seria, propriamente, o começo das visões. Agora o autor, que também é testemunha ocular ("vi") de tudo o que vai narrar, é transportado para uma realidade superior. Essa deslocação é realizada pelo Espírito, ele entra no céu e lá vê o trono $(\mathrm{Ap} \mathrm{4,2)}$ e lá lhe é mostrado como deveriam acontecer as coisas em breve (Ap 4,1). O trono está no céu (Is 66,1; S1 11,4; 93,2; 97,2). O Filho, ao lado do Pai, não está mais na Galiléia, nem na Samaria, nem sobre o monte Sião, mas em um lugar de poder (cf. 5,6.12; 6,1), agora Jesus reina como Rei da História (Mt 25,3146). Jesus não é mais um jovem revolucionário, anarquista, procurado para ser morto, mas é um ancião, um sábio e alguém que sabe tudo sobre a história humana e tem o poder do julgamento em suas mãos. O Cordeiro tem seu trono acima de todos os tronos e dele saem vozes, luzes, relâmpagos e ao redor sete lâmpadas acesas e sete Espíritos de Deus (Ap 4,5), indicando que nele está toda a luz e toda a sabedoria (Cf. Is 11,1ss; Ez 1,13; Zc 4,2).

A primeira parte da visão centraliza-se sobre a descrição do trono celeste. A visão da porta, "êneôgmenê", indica que a porta está aberta e ele tem acesso à porta do céu, o mais alto dos santuários. ${ }^{19}$. Os anciãos se prostram diante do trono. A descrição dos adornos e das pedras preciosas, muitas desconhecidas para o ambiente do autor, indicam a realeza e a soberania da onipotência divina.

A voz, que ele ouviu com a ordem de escrever as cartas $(1,10)$, é a mesma que ele agora ouve e lhe ordena, imperativamente, para subir até a porta $(4,1)$. O livro já mencionou outras portas, que não devem ser confundidas com esta porta: uma foi a porta do Reino $(3,8)$, outra a porta do coração

\footnotetext{
${ }^{19}$ MOUNCE, R., Idem, 118.
} 
$(3,20)^{20}$ e essa é a porta do céu $(4,1)$. Ele deve subir para conhecer e ver o que vai acontecer depois. $\mathrm{O}$ fato fundamental é que o trono está nos céus. $\mathrm{O}$ "céu não é uma pintura como o templo ou a sinagoga, mas um trono com uma sala de um grande rei". ${ }^{21}$ A sala do trono do rei celeste não tem similar sobre a terra. Nenhum rei consegue ter tanto prestígio, tanto reconhecimento e tanto luxo. As pedras de jaspe, descritas no livro (cf. 21,11), não são o jaspe opaco, como conhecemos hoje, mas um belo cristal translúcido. É provável que se tratasse de um diamante de cristal. ${ }^{22}$ Os 24 anciãos representam uma realidade do passado e uma realidade presente: doze anciãos representam o AT, a história do passado, os patriarcas e os profetas; outros doze representam os apóstolos e com eles tudo aquilo que é atual ${ }^{23}$.

$\mathrm{O}$ vidente não teria entrado nos céus, mas em êxtase. Ele caminha em meio aos candeeiros de ouro, sem menção alguma a portas celestiais, podemos concluir que a porta que João viu depois, em êxtase, é uma metáfora. Esta conclusão é sustentada pela grande facilidade com que as cenas no Apocalipse mudam do céu para a terra. João, em sua visão, é levado ao céu, mas essa visão é importante para a terra, para os companheiros de João que continuam na luta de cada dia.

A conexão de João, no conjunto da visão, mostra que ele está aberto para a voz do alto. Ele ouvira a voz $(1,10)$ que o mandava escrever às igrejas, uma missão na terra, mas essa voz, a mesma, tem uma missão para ele nos céus $(4,1)$.

Rodeando o trono, estão outros vinte e quatro tronos ocupados por 24 anciãos, com vestes brancas e coroas de ouro, caracterizando uma condição de realeza e transcendência, ou autoridade celeste $(4,4)^{24}$. Em 21,12-14 os nomes

\footnotetext{
${ }^{20}$ LADD, G., Apocalipse, 54.

${ }^{21}$ MOUNCE, R., Idem, p. 119.

${ }^{22}$ IRONSIDE, H. A., Idem, 50. A mesma posição, em relação à diferença entre a descrição dos cristais do trono e os atuais é sustentada por MOUNCE, R., Idem, 120.

${ }^{23}$ Para alguns autores, os vinte e quatro anciãos incorporam uma lista de inclusão: doze anciãos são os doze patriarcas e outros doze são os apóstolos, cf. IRONSIDE, H. A., Revelation, 50.

24 "A identidade dos vinte e quatro anciãos ao redor do trono tem sido largamente discutida. Alguns comentadores tentam encontrar a fonte na qual João se inspirou para essa cena. Para muitos, ela procede da tradição mitológica do Oeste politeísta da Babilônia, associado aos anciãos de Israel com as vinte e quatro estrelas divinas do panteon babilônico. Outros interpretam simbolicamente associando com as vinte e quatro classes sacerdotais de Aarão (1Cron 24,5), os quais, nos céus rendem honra a Deus, o sacerdote perfeito sobre a terra, mas essa é uma imagem imperfeita" (MOUNCE, R. H., Idem, 121). Beasley-Morray rejeita a teoria de que os vinte e quatro anciãos tenham origem na religão astrológica da Babilônia, via apocalíptica judaica (como propuseram Zeimmer e Gunkel) na base de que "não hã evidencias de que a apocalíptica judaica conheceu uma ordem angelical de vinte e quatro nos céus", 115, n.1 Cf. MOUNCE, Idem, nota, 13.
} 
das Doze tribos de Israel estão gravados nos doze portões da Nova Jerusalém, e os nomes dos Doze Apóstolos estão nos seus doze fundamentos. Em 5,8, esses vinte e quatro anciãos, juntamente com os outros quatro Seres vivos, adoram o Cordeiro, com cítaras e taças de ouro em suas mãos, cheias de incenso, que são as orações dos santos, cantando um canto novo... Eles assumem uma função de mediação, enviando as orações a Deus, diante do trono Cordeiro. Como observa Ladd, um dos anciãos exerce uma função própria dos anjos, em 7,13-14, inadequada para um redimido, e João se dirige a ele, muito respeitosamente, como "senhor", título não apropriado para um irmão na fé. ${ }^{25}$

A veste branca e a coroa de ouro remetem a um rito litúrgico, cultual e reverencial. A veste branca, característica do sacerdote no exercício cultual e a coroa, representa autoridade, poder e realeza. Trata-se de uma sintonia entre o exercício do sacerdócio real, como ato de sacrifício cúltico, com a realeza divina representada pela coroa de ouro, através da qual, ele honra a Deus e o Cordeiro $(4,8 ; 5,8)$. Assim os anciãos, no seu lugar de poder, prestam honra e culto ao Cordeiro, pois é ele que tem o livro na mão direita e o poder de abrir suas páginas seladas $(5,1 \mathrm{ss})$. Essa imagem cultual, da cena descrita por João, foi interpretada por alguns autores como sendo a igreja vitoriosa, redimida e celeste $^{26}$. Contudo, a igreja redimida tem outra característica, é a de multidão, de inclusão e de presença maciça, onde os fiéis não se apresentam com coroas, mas com palmas nas mãos. A palma é o símbolo da vida, da vitória e do canto (cf. 7 e 14).

O trono é guardado por quatro animais, como era guardado na religiosidade antiga, mostrando sua inviolabilidade. Os animais são protetores do trono e possuem asas para alcançar o destino como se fossem anjos. Guardando o trono de Deus, os quatro animais protetores asseguram a sua soberania (Ap 4,6b; Ez 1,5-20; 10,14). Estes animais possuem quatro faces para poder ter a totalidade do conhecimento do que se passa nas quatro direções e aclamam o Cordeiro:

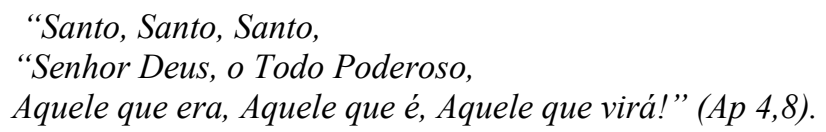

A liturgia celeste era contrária à liturgia terrestre do templo de Jerusalém. Na terra, os homens haviam matado o Filho de Deus, o Santo e o Justo

\footnotetext{
${ }^{25}$ LADD, G., Apocalipse, 57.

${ }^{26}$ Cf. LADD, G., Apocalipse, 50; IRONSIDE, H. A., Revalation, 51; MOUNCE, R., The Book of Revelation, 121.
} 
(At 3,14-15), mas no céu os animais e os vinte e quatro anciãos adoram a Deus $(4,8)$ e ao Cordeiro $(5,8)$ com toda a honra e toda a glória.

À frente do trono havia um mar vítreo, semelhante ao cristal $(4,6)$, contrastando com a compreensão do mar nas crenças populares e na mentalidade judaica que entendia o mar com sendo a morada dos monstros e dos demônios (cf. Mc 5,1-20). ${ }^{27}$

A visão do trono celeste servia para ironizar os tronos terrestres. De um lado estava o poder da sinagoga e do outro o do Império romano. Esses tronos disputavam o poder e a força no comando da verdade, das sentenças dos vivos e dos mortais. Para os cristãos, humilhados e sofridos pelas perseguições destas forças hostis à verdade e à justiça, era consolador saber que havia um trono celeste e nesta certeza eles se encorajavam na luta e na resistência do testemunho do Evangelho ${ }^{28}$. Essa visão pode reforçar a dimensão profética do sacerdócio de Cristo e do sacerdócio dos cristãos, que não raro passa por difamações, calúnias e perseguições. $\mathrm{Na}$ verdade, os redimidos são os que alvejaram suas vestes no sangue do Cordeiro e vieram de uma grande tribulação $(7,14)$. É possível que no céu haja poucos tronos para reis, magnatas é déspotas mentirosos (cf. 22,15).

\subsection{A visão daquele que está sentado no trono}

Um lacre comum pode ser violado por uma pessoa simples, mas sete lacres (sete chaves) seria impossível abri-los sem conhecer os seus segredos. A vida é como um livro que tem sete chaves para ser aberto, é como um cofre inviolável com sete segredos, este só poderá ser aberto por quem possui as respectivas chaves. A associação do Rolo (livro) com a história vem de Ez 2,9-3,3; (Cf. Ap 10,8-10). Só Ele é capaz de abrir o livro, escrito frente e verso, pois o livro está na mão direita daquele que está sentado $(5,1)$, mas agora Ele, o Leão da Tribo de Judá, recebe a autoridade e poder de agir, mostrando uma grande sintonia entre o Ancião sentado e o Cordeiro em pé, no julgamento final $(5,6 \mathrm{ss})$.

Estamos numa visão beatífica, o trono celeste, uma realidade superior dentro da história. O cenário é realmente apocalíptico, pois tudo converge para o trono e para o Cordeiro, que está de pé, em posição de ação, e recebe o livro (a História de cada um dos seres humanos) em suas mãos, com o

\footnotetext{
${ }^{27}$ Ao expulsar os demônios do homem possesso, eles pedem para entrar nos porcos (conceito de impureza) e os porcos se precipitam no mar voltando ao seu ambiente original, (Cf. Mc 5,12-13).

${ }^{28}$ Cf. MAZZAROLO, I., Idem, 28-29.
} 
poder de julgar e determinar o veredicto jurídico final. O termo grego "acsios" = digno, tem um sentido jurídico de capacidade, autoridade e poder (5,9$14)^{29}$. Nesse caso, o Ancião está sentado, com posição de autoridade jurídica, de função especial de julgamento $(4,2)$. Do seu trono saem relâmpagos, trovões e vozes e diante do trono estão sete lâmpadas ardendo, que são os sete Espíritos de Deus $(4,5)$. Os trovões e vozes apontam para a autoridade e o poder superior de Deus e os sete Espíritos revelam a onipotência, a sabedoria cósmica e total de Deus. Só Deus possui todo o saber, só Ele é a fonte da ciência e da onipotência, que usa os Espíritos para fazer graça e justiça (cf. Is $11,1-5)$.

"Cada vez que os seres vivos davam glória, honra e ação de graças àquele que estava sentado no trono, àquele que vive pelos séculos dos séculos, os vinte e quatro anciãos se prostravam diante daquele que estava sentado no trono, adoravam aquele que vive pelos séculos dos séculos e depunham suas coroas diante do trono, dizendo: Tu és digno, Senhor Deus nosso, de receber a glória, a honra e o poder, pois criaste o universo e por tua vontade foi criado e existiu” (Ap 4,9-11).

Numa breve analogia com o Cordeiro, Jesus Cristo como Senhor da História, do ontem, do hoje e amanhã, recebe o livro (Ap 5,7) escrito dos dois lados (Ap 5,1). Este é um rolo totalmente desconhecido, misterioso, já anunciado por Ezequiel (2,9-10), com seus selos em função do conteúdo (Is 8,16; Dn 12,4-9). O autor continua a narrativa (Ap 6,1) dizendo: "Kai eidon" = "Eu vi o Cordeiro que abria o primeiro dos sete selos". Para abrir o livro ele precisava romper os sete segredos. Cada selo tinha um significado. ${ }^{30}$

O sexto selo corresponde ao Grande dia do Julgamento (Ap 6,12$7,17)$. Neste dia, os magnatas, os reis, os capitães, os poderosos, os escravos $e$ os homens livres procurarão esconderijos nas cavernas em sinal de medo do fim $^{31}$. O Cordeiro estará de pé e diante dele comparecerão os 144.000 de todas as tribos para o julgamento: "Depois disso, eis que vi uma grande multidão, que ninguém podia contar, de todas as nações, tribos, povos e línguas. Estavam de pé diante do trono do Cordeiro, trajados com vestes brancas e palmas na mão" (Ap 7,9). O traje branco corresponde à grande bemaventurança do próprio texto (Ap 7,14; Cf. Mt 5,11-12; Lc 6, 22-23). Uma

\footnotetext{
${ }^{29}$ BAUER, W., "acsios".

${ }^{30}$ Para uma descrição do significado simbólico de cada animal presente mais próximo do trono do Ancião e suas interpretações na Igreja, cf. MAZZAROLO, I., Apocalipse, 48-50.

${ }^{31}$ MAZZAROLO, I., Apocalipse, 50.
} 
frase de Tertuliano, guardada na memória da história, afirma: "O sangue dos mártires é semente de novos cristãos". O testemunho do Evangelho levava muitos cristãos a "alvejaram sua vida" no derramamento de seu sangue em prol da verdade, da justiça e da misericórdia. O sexto selo, ao falar dos 144.000 que serão redimidos, ultrapassa todos os conceitos e prognósticos cabalísticos. Salvar-se-ão os que testemunharem o Evangelho da verdade até o fim e até as últimas conseqüências.

A abertura do sétimo selo é enigmática. Neste momento se faz um silêncio de meia hora no céu. Não é um tempo longo, nem é um tempo curto demais. É o fim dos enigmas, agora tudo está apresentado. Este silêncio é uma exigência de postura diante de Yahweh, que é Senhor absoluto do universo. O silêncio é uma atitude de escuta. $\mathrm{O}$ silêncio faz parte do tempo de espera, da tensão e também da angústia na expectativa de algo que vai acontecer. O silêncio é o tempo de concentração para que, quando a voz do alto falar, não haja possibilidade alguma de desperdiçar a atenção. Para o povo do AT havia um ritual para esperar a voz de Deus a falar ao povo: "Ouve, oh Israel, o Senhor nosso Deus, é o único Deus" (Dt 6,4). A presença de Deus exige silêncio a fim de que sua palavra possa ser ouvida e respondida. $\mathrm{O}$ silêncio é o respeito, a reverência e também o temor ${ }^{32}$.

As culturas antigas valorizavam o respeito dos menores aos maiores. Assim quando Yahweh decidisse falar, todo o respeito era pouco, para tanto, o silêncio, a reverência e a submissão eram grandes valores. Na profecia de Habacuc (Há 2,20), quando Deus entra no seu santuário para o Julgamento final, a terra inteira fará silêncio para ouvir atentamente as determinações sobre o destino de cada criatura. O silêncio envolve o enigmático, o programático e também o caótico ou o êxtase. O silêncio é a expressão do suspense, do admirável e também do incompreensível. O silêncio é a ansiedade, a incerteza e o temor do que está por acontecer.

$\mathrm{Na}$ abertura do sétimo selo (Ap 8,1) acontece uma passagem de cenário: os sete selos estão abertos, está decifrado todo o enigma inicial, mas há uma continuidade dramatúrgica, uma vez que aparece um novo cenário protagonizado por outros sete anjos, os quais recebem de Deus sete trombetas (Ap 8,2).

Dentro do quadro enigmático, a abertura do último segredo (selo) indicaria que não há mais nada na história que não seja conhecido. No entanto, o último selo abre um novo cenário. Neste último segredo, a grande mudança: O incenso da liturgia era um produto da natureza, trabalhado para amenizar o enjôo da gordura dos animais queimados nos sacrifícios antigos, agora

${ }^{32}$ MAZZAROLO, I., Idem, 54. 
não será o produto aromático produzido pela terra e pela mão humana, mas será a oração dos fiéis ao Cordeiro (Ap 8,4). O turíbulo, instrumento próprio para queimar incenso e perfumar as liturgias sacrificiais é enchido com brasas (não é posto incenso) e arremessado à terra por um anjo (Ap 8,5), indicando agora que o perfume das liturgias será o testemunho dos cristãos e suas orações. Completava-se agora a profecia de Oséias (6,6; Cf. Mt 12,7) onde Jesus afirmava que era a misericórdia que ele desejava e não os sacrificios. De modo análogo, na profecia de Isaías 58,6-7, na qual há uma mudança substancial no conceito de jejum, a qual, em lugar de deixar de comer e beber propõe a libertação dos escravos, a ruptura das injustiças e a instrução dos ignorantes e cegos fazendo-os ver com os próprios olhos.

Aquele que estava no trono central, no centro dos vinte e quatro tronos laterais, era aquele que eles precisavam acolher e acreditar em tudo aquilo que ele havia mostrado, ensinado e realizado:

a) Jesus Cristo nos lavou dos nossos pecados com o seu sangue $(1,5 b)$. O sangue se torna elemento de purificação e participação no processo de redenção. O sangue torna-se uma bem-aventurança, como associação no caminho da redenção do Cordeiro e de seus discípulos (Ap 7,14; 22,14).

b) Jesus Cristo é testemunha fiel (ho pistós) da missão e da revelação do Pai, cuja palavra deixou no meio dos homens em sinal de verdade e de Lei. Como Mediador, entre o Pai e os homens, Jesus é o Evangelho do Pai para os seus filhos, o seu servo fiel ( $\mathrm{Hb}$ 7,26-28), o amado, no qual Deus colocou todo o seu bem querer (Mc 1,11 e par.).

c) Jesus Cristo é o primogênito dos mortais (Ap 1,5; Cf. Cl 1,15.18). No momento em que ele aceita assumir a natureza humana (Fl 2,5-11), rejeitando o mal e testemunhando o modo de ser de Deus Pai, Jesus se torna o arquétipo de todo o ser humano. Na sua humanidade, Jesus Cristo revela a humanização de Deus e a possibilidade da divinização do ser humano (Jo 1,12-13).

d) Jesus Cristo é o Alfa e o Omega (Ap 1,8). Jesus é o Cordeiro que tem a possibilidade de abrir todos os segredos da história, todas as verdades e de desmascarar todas as mentiras (Ap 5,9ss). Ele é a razão principal da história humana (Ap 1,8; 21,6; 22,13).

e) Jesus Cristo é o Todo Poderoso (Pantocrator). Diante de uma infinidade de ídolos que sustentavam a mitologia greco-romana, o autor do Apocalipse reforça para nos cristãos a pedagogia de Jesus de Nazaré na busca da misericórdia, da compaixão, da verdade e da justiça, pois ele será o juiz último da história. A hora da adoração e da salvação é agora (Jo 4,23). Ele estará sentado no trono, na posição de Rei (Ap 1,8.12-13; 4,8; 5,1; 19,6). 


\subsection{A porta aberta nos céus 4,1}

A visão da porta aberta nos céus não pode ser apenas uma imaginação, uma abstração ou fruto da "phantasia" (criação imaginária) como afirma Becatti ${ }^{33}$. A visão do céu, uma porta aberta é um sinal verde para o vidente passar de uma situação para outra. Como a porta está acima, no céu, o vidente é convidado a dar um passo acima, subir, transcender a esfera donde se encontra. $\mathrm{Na}$ opinião de Charles a visão da porta pode ser interpretada de dois modos:

a) $\mathrm{O}$ vidente pode ser compreendido como alguém que já esteve no céu. Neste caso, a porta mencionada pode deixar para o santificado uma parte do céu, como será mostrado ao mesmo depois. Esta é uma visão semelhante à de Henoc (1Hn 14). Henoc é transportado para dentro do céu, ele vê uma grande parede de cristal e línguas que circundam (vozes) a grande casa (Hn 14,9).

b) $\mathrm{O}$ vidente não entra no céu, mas coloca-se junto à porta, como no Testamento de Levi, 5,1. Esta porta permite a Levi passar do segundo para o terceiro céu, o que, no entanto, não parece ser o caso do nosso vidente do Apocalipse.

A porta é sempre uma passagem, uma mudança de cenário e uma abertura para outra realidade. O céu está fechado para o mau, para o impudico, o canalha e o amante da mentira (Ap 22,15), mas estará aberto para aque-

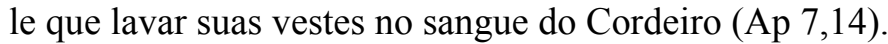

João vê a porta aberta e, antes que ele pense no que vai fazer, a voz o convida a subir "anaba" (sobe). Este subir é visto de modo diferenciado pelos exegetas. Prigent ${ }^{34}$ afirma que não significa que a primeira visão se tenha dado na terra (a voz ouvida 1,10 ). Charles $^{35}$ afirma que este convite a

\footnotetext{
${ }^{33}$ Citando Quintiliano, Becatti ("Visione", in: Enciclopedia dell'arte ântica) afirma que as visões permitem recriar no ânimo imagens de coisas longínquas, de fantasias ou de saudades. $\mathrm{Na}$ sua conceituação, o autor afirma que a visão é uma recriação de algo que já está incutido na mente e que aflora apenas num estado e êxtase furtivo. Interpretando a visão neste quadro, o autor está negando toda a possibilidade da revelação. A visão é, por excelência, a revelação gratuita, acidental e não programada. Equivocadamente Becatti associa a visão à "fantasia". A fantasia é o resultado da elucubração mental. A revelação (visão) não está ligada à elucubração mental, ao desejo ou anseio de ver criado pela necessidade. A fantasia é a visão falsa ou equivocada, projeção do consciente ou inconsciente da pessoa. É um resultado de dentro para fora. A visão é revelação de fora para dentro. $\mathrm{O}$ vidente recebe algo gratuito que não é para ele somente, mas para ser transmitido aos outros (Ap. 1,1).

${ }^{34}$ PRIGENT, P. L'Apocalypse de saint Jean, 134.

${ }^{35}$ CHARLES, R. H. A Critical and Exegetical Commentary on the Revelation of St. John, 109.
} 
subir é uma passagem da realidade dos homens, da terra para uma realidade celeste. Esta porta aberta e este imperativo "sobe" situam o vidente no privilégio de ver como se comporta o céu, o que há nele e o que ele pode contar aos seus patrícios o que tinha visto. Para Läpple ${ }^{36}$, a porta aberta significa a visão inaugural (o autor reconhece que os três primeiros capítulos são uma introdução, não essencial ao livro) na qual o autor tem uma visão celestial privilegiada, sem méritos e dá ao vidente um panorama desconcertante e patético (Cf. Ex 3,3; 1Sm 3,15; Jr 14,14; 23,16; Dn 7,1ss).

\section{Conclusões}

As visões são uma ascensão no espírito que permite ao vidente passar para outra dimensão e ver (entender, conhecer e depois transmitir) uma outra realidade. Os profetas são videntes e conhecem de modo intuitivo ou indutivo a mensagem que Deus lhes revela (deixson $=$ mostrarei) o que vai suceder (Am 7,1-9; Jr 1,11-24; Ez 3,1ss).

As visões não são fruto da especulação intelectual, nem são produtos captados pela esfera racional (Cf. 1Cor 13,12; 1Jo 3,2). É uma passagem para uma outra esfera, algumas vezes com a abstração da razão, outras dentro de um domínio perfeito dos sentidos, mas sem o controle ou a possibilidade de manipular o que lhe é revelado.

Nos tempos atuais, se dá uma certa tensão entre o vidente místico e o racionalista ateu. A esfera espiritual se projeta para o alto e lança prognósticos concretos, revelações de fatos e acontecimentos incapazes de seres captados pelas especulações racionais, por isso a postura pragmática sente-se humilhada diante da visão espiritual que antecipa, que prenuncia e denuncia uma realidade possível e às vezes próxima de acontecer.

Na história cristã há muitas, para não dizer incontáveis visões. Elas superam todos os aspectos racionais e quando se manifestam desconcertam o racionalismo puro e pragmático, como é o caso do Apóstolo Paulo (At 9,1ss), o qual, de perseguidor frio e calculista, vê uma luz e ouve uma voz (At 9,3-4). Assim podem ser mencionadas muitas visões e discutidos com os mais diferentes argumentos, mas sobra sempre, no fim de cada uma delas, uma mensagem transcendente, uma provocação a "subir" no caminho da conversão e da fé, acreditando que Deus é o senhor da história e tem para cada tempo sua mensagem e sua revelação. Como afirma o evangelista João, Jesus não podia ter dito tudo, pois a capacidade de entendimento é sempre

${ }^{36}$ LÄPPLE, A. L'Apocalypse de Jean. Livres de vie pour les Chrétiens, 107. 
parcial, por isso, há uma necessidade de transporte no Espírito para entender toda a revelação (Jo 16,12-14).

As visões são uma amostra do amor de Deus e de sua presença dinâmica na história dos seres humanos. A cada tempo se faz mister a revelação para $o$ perfeito entendimento da vontade de Deus e da necessidade de encontrar o seu caminho no amor recíproco e na justiça (Mt 5,20; Jo 13,34-35).

Resta, depois disso, um imperativo aos homens e mulheres de consciência ética, independentemente da cor, raça ou credo, proclamar e defender a verdade e a justiça acima dos interesses militares, despóticos, tiranos de grupos econômicos, ideológicos e sanguinários. Os homens e mulheres de boa vontade precisarão fazer um grande esforço, concentrar e reunir coragem para combater as bestas das oligarquias dominadoras, mentirosas e despóticas, do mercado e da cultura da morte, que em nome do desenvolvimento tecnológico concentram a renda e distribuem a miséria. $\mathrm{O}$ desenvolvimento tecnológico está matando a civilização do amor e da justiça. Ter visões verdadeiras e autênticas é conceber novamente a utopia de um Paraíso terrestre (Is 11,1-9), onde a vida e o amor se tornem uma nova página da realidade.

Em última análise, o trono do julgamento está nos céus e quem está nele sentado é Deus. Os tronos terrestres não passam de mediações que podem construir a verdade ou a mentira, mas todos serão responsabilizados pelas suas atitudes. Alguns ficarão fora como os cães, os magos, os impudicos, os homicidas, os idólatras e todos os que amam e praticam a mentira $(22,15)$.

\section{Résumé}

La vision du trône dans l'Ap 4 révèle la souveraineté de Dieu, qui, outre avoir toute la sagesse et la connaissance, est assis dans le trône, dans les cieux. Il reçoit l'honneur et la reconnaissance de tous les peuples et les générations, donc son autorité n'a pas de frontières. Seulement Il est digne de de recevoir toute l'honneur, la gloire et le pouvoir, donc seulement Il est M., Dieu toutpuissant.

Isidoro Mazzarolo

Professor da PUC-Rio

Professor do Instituto Franciscano de Petrópolis

Professor do Instituto Paulo VI de Nova Iguaçu

isidoro@puc-rio.br mazzarolo.isidoro@gmail.com 


\section{Bibliografia}

"Vision", in: Enciclopedia Universal Ilustrada Europeo-Americana SPASA CALPE. V. LXIX, Madrid/Barcelona, 1930.

"Visione", in: Enciclopedia filosófica. Roma/Venezia: Istitutto per la Collaborazione Culturale, 1957.

BAUER, W., Wörterbuch zum Nenem Testament, Berlin, De Gruyter, 1971.

BECATTI, G. "Visione", in: Enciclopedia dell'arte antica, classica e orientale. Roma: Istitutto della Enciclopedia Italiana, v. VIII, 1966.

CHARLES, R. H. A Critical and Exegetical Commentary on the Revelation of St. John. Edinbourg: T\&T Clark, 1971.

DATTER, F. O livro da Revelação - Comentário sobre o Apocalipse. São Paulo: Loyola, 1977.

FEUILLET, A. L'Apocalypse - État de la question. Paris: Desclée, 1963.

HAAG, H. Bibel-Lexicon. Zürich: Verlag, 1968.

IRONSIDE, H. A. Revelation, Michigan, 2007.

LADD, George, Apocalipse, Introdução e comentário, São Paulo, Vida Nova, 2006.

LÄPPLE, A. L'Apocalypse de Jean. Livres de vie pour les Chrétiens. Paris: Cerf, 1966.

LELANDE, A. Vocabulário Técnico e Crítico da Filosofia. São Paulo: Martins Fontes, 1999.

MAZZAROLO, I. Apocalipse, esoterismo, profecia ou resistência? Rio de Janeiro: Mazzarolo editor, 2000.

MESTERS, C., OROFINO, F. Apocalipse de João; Esperança, Coragem e Alegria. São Leopoldo/Cebi - São Paulo/Paulus, 2002.

MONLOUBOU, L. "Visão", in: Dicionário bíblico universal. Petrópolis: Vozes, 1997.

MOUNCE, Robert H., The Book of Revelation, revised, Michigan, Eerdmans Publishing Company, 2008.

POZA, C. "Visão", in: Enciclopédia Luso-Brasileira de Cultura.v. 18. Lisboa: Ed. Verbo, 1976.

PRIGENT, P. L'Apocalypse de saint Jean. Paris: Delachaux et Niestlé, 1982. ROLOF, J. Die offenbarung dês Johannes. Zürich: Verlag, 1984.

ROSA, E. "Visione", in: Enciclopédia Italiana di Scienze, Lettere ed Arti. Roma: Istituto della Enciclopédia, 1950. 